\title{
Expression of CD27 and CD28 on $\gamma \delta$ T cells from the peripheral blood of patients with allergic rhinitis
}

\author{
QIONG WANG, QUN SUN, QIGUO CHEN, HAO LI and DING LIU \\ Department of Otolaryngology, Shiyan People's Hospital of Baoan District in Shenzhen City, \\ Shenzhen, Guangdong 518108, P.R. China
}

Received April 26, 2020; Accepted September 16, 2020

DOI: $10.3892 /$ etm.2020.9354

\begin{abstract}
The costimulatory receptors CD27 and CD28 have pivotal and non-redundant roles in the activation and differentiation of $\gamma \delta$ T-cells. However, the roles of CD27 and CD28 on $\gamma \delta$ T-cells in allergic rhinitis (AR) have remained elusive. The aim of the present study was to investigate the expression of CD27 and CD28 on $\gamma \delta$ T cells in patients with AR. Peripheral blood mononuclear cells from 14 patients with AR and 12 healthy subjects were isolated and analyzed by flow cytometry to determine the percentage of $\gamma \delta$ T cells and regulatory T cells (Tregs), and the expression of IFN- $\gamma$, IL-17A, CD27 and CD28 on $\gamma \delta \mathrm{T}$ cells. The correlations between the expression of $\mathrm{CD} 27$ and $\mathrm{CD} 28$, and the percentages of IFN- $\gamma^{+}$and IL-17A $\mathrm{A}^{+} \gamma \delta$ T-cell subsets and Tregs in AR were analyzed. It was observed that the percentages of $\gamma \delta$ $\mathrm{T}$ cells, and the IL-17A ${ }^{+}, \mathrm{CD} 27^{-} \mathrm{CD} 28^{+}$and $\mathrm{CD} 27^{-} \mathrm{CD} 28^{-} \gamma \delta$ T-cell subsets were significantly increased, while the percentages of Tregs and IFN- $\gamma^{+}$and $\mathrm{CD} 27^{+} \mathrm{CD} 28^{+} \gamma \delta$ T-cell subsets were significantly decreased in AR. Of note, the percentage of $\mathrm{CD} 27^{+} \mathrm{CD} 28^{+} \gamma \delta \mathrm{T}$-cell subsets was positively correlated with that of the IFN- $\gamma^{+} \gamma \delta$ T-cell subset and the percentage of the $\mathrm{CD} 27^{-} \mathrm{CD} 28^{+} \gamma \delta \mathrm{T}$-cell subset was positively correlated with that of the IL-17A ${ }^{+} \gamma \delta \mathrm{T}$-cell subset. Furthermore, the percentages of $\gamma \delta$ T cells and the CD27-CD28+ $\gamma \delta$ T-cell subset were both negatively correlated with that of Tregs. Therefore, the results of the present study indicate that CD27 and CD28 may be the key signals for activation of different $\gamma \delta$ T-cell subsets
\end{abstract}

Correspondence to: Dr Qiong Wang, Department of Otolaryngology, Shiyan People's Hospital of Baoan District in Shenzhen City, 11 Jixiang Road, Baoan, Shenzhen, Guangdong 518108, P.R. China

E-mail: fzrm2000@126.com

Abbreviations: AR, allergic rhinitis; $\mathrm{HC}$, healthy control; PBMCs, peripheral blood mononuclear cells; TCR, T-cell receptor; Th, $\mathrm{T}$ helper; TNFR, tumor necrosis factor receptor; Treg, $\mathrm{T}$ regulatory cell

Key words: allergic rhinitis, $\gamma \delta \mathrm{T}$ cells, CD27, CD28 and may contribute to the immune regulatory function of $\gamma \delta$ $\mathrm{T}$ cells in the peripheral blood of patients with AR.

\section{Introduction}

Allergic rhinitis (AR) is an inflammatory reaction mainly mediated by immunoglobulin ( $\mathrm{Ig}) \mathrm{E}$ after inhaled allergens enter the body through the nasal mucosa and it is the manifestation of a systemic allergic disease in the upper respiratory tract (1). The pathogenesis of allergic inflammation of the nasal mucosa is the result of the interaction among environmental pathogenic factors, genetic susceptibility and the local and systemic immune defense system, in which the imbalance of immune response is a critical factor (2). However, the mechanism driving the immunological imbalance in AR remains elusive.

The $\gamma \delta \mathrm{T}$ cells, which are predominantly located in the mucosa, have an important role in mucosal immune processes and are considered to act as the connection between innate and acquired immunity (3). $\gamma \delta \mathrm{T}$ cells are characterized by the expression of the T-cell receptor (TCR) $\gamma \delta$ and may be further divided into different functional subsets, exerting their regulatory effects on immune balance by secreting IFN- $\gamma$ or IL-17A $(4,5)$, as well as by affecting the differentiation and function of other types of immune cell, such as regulatory T cells (Tregs) $(6,7)$. It was previously demonstrated that different subsets of $\gamma \delta \mathrm{T}$ cells predominantly expressed in the mucosa and epithelium of the respiratory tract may have a pro- or anti-inflammatory role under different conditions, and they are crucial for regulating the occurrence and persistence of allergic inflammatory conditions, including AR (8-10). However, the molecular factors that steer $\gamma \delta$ T cells to differentiate into different functional subsets in AR remain elusive.

CD27 and CD28 are two major costimulatory molecules with independent and non-redundant roles in the activation, proliferation and survival of $\gamma \delta$ T cells $(11,12)$. Studies in mice have demonstrated that $\mathrm{CD} 27^{+} \gamma \delta \mathrm{T}$ cells produce IFN- $\gamma$, whereas CD27 $\gamma \delta$ T cells produce IL-17 (13), while the population of IFN- $\gamma^{+}$and IL-17 $7^{+} \gamma \delta \mathrm{T}$ cells failed to expand during infection in CD28-deficient mice $(14,15)$, indicating the essential roles of CD27 and CD28 co-stimulatory signals in the activation of specific functional subsets of $\gamma \delta \mathrm{T}$ cells. However, the roles of CD27 and CD28 on $\gamma \delta$ T cells have not 
been extensively investigated in humans, and have not yet been reported in AR. The aim of the present study was to explore the expression of CD27 and CD28 on $\gamma \delta \mathrm{T}$ cells in patients with AR.

\section{Materials and methods}

Subjects. The present study was approved by the Ethics Committee of the Shiyan People's Hospital of Baoan District in Shenzhen City (Shenzhen, China). Written informed consent was provided by all subjects or their legal guardians prior to participation. A total of 14 volunteers with AR were enrolled at the Department of Otolaryngology, Shiyan People's Hospital of Baoan District (Shenzhen, China) between December 2018 and October 2019. The diagnosis of AR was made based on the Allergic Rhinitis and Its Impact on Asthma guidelines (2). To evaluate the atopic status, the concentrations of serum $\operatorname{IgE}$ specific to local common inhalant allergens were detected using the automatic system of immunofluorescence quantitative analysis (UniCAP 100E; Pharmacia Biotech). A concentration $>0.7 \mathrm{IU} / \mathrm{ml}$ was considered as the positive diagnostic criterion for AR. In addition, 12 healthy control (HC) volunteers were recruited, each with no clinical symptoms of any allergic disease and negative serum IgE. Subjects who received oral glucocorticoids, antihistamines or immunotherapy within 1 month were excluded. The characteristics of AR and HC subjects are listed in Table I. Peripheral venous blood samples anticoagulated with heparin were collected from each subject.

Flow cytometry. Peripheral blood mononuclear cells (PBMCs) were isolated from whole blood samples using the Ficoll-Hypaque gradient centrifugation method. First, the cells were suspended in PBS with $0.5 \%$ bovine serum albumin (BSA; MP Biomedicals, LLC) to prevent unspecific binding. Prior to fluorescence antibody staining, cells were first incubated with Fixable Viability Dye eFluor $780(1 \mu \mathrm{g} / \mathrm{ml}$; cat. no. 65-0865-14) for $20 \mathrm{~min}$ at room temperature to confirm their viability. For cell surface staining, cells were incubated with APC-conjugated CD3 (clone: UCHT1) monoclonal antibody (2.5 $\mu \mathrm{g} / \mathrm{ml}$; cat. no. 17-0038-41), FITC-conjugated TCR $\gamma / \delta$ (clone: 5A6.E91) monoclonal antibody $(10 \mu \mathrm{g} / \mathrm{ml}$; cat. no. TCR2061), PE-Cyanine5-conjugated CD27 (clone: O323) monoclonal antibody $(2.5 \mu \mathrm{g} / \mathrm{ml}$; cat. no. $15-0279-42)$ and PE-conjugated CD28 (clone: CD28.2) monoclonal antibody $(2.5 \mu \mathrm{g} / \mathrm{ml}$; cat. no. 12-0289-42) (all from eBioscience) for $30 \mathrm{~min}$ at $4^{\circ} \mathrm{C}$. For transcription factor staining, cells were first incubated with PE-Cyanine5-conjugated CD3 (clone: UCHT1) monoclonal antibody $(0.6 \mu \mathrm{g} / \mathrm{ml}$; cat. no. $15-0038-42)$ for $30 \mathrm{~min}$ at $4^{\circ} \mathrm{C}$, then fixed and permeabilized with the Forkhead box p3 (Foxp3)/Transcription Factor Staining Buffer Set following the manufacturer's protocol at room temperature, and incubated with APC-conjugated Foxp3 (clone: PCH101) monoclonal antibody (5 $\mu \mathrm{g} / \mathrm{ml}$; cat. no. 17-4776-42) for $60 \mathrm{~min}$ at room temperature (all from eBioscience). For intracellular cytokine staining, cells were first cultured in RPMI-1640 medium supplemented with heat-inactivated fetal bovine serum (10\%) and penicillin/streptomycin (1\%) (all from Gibco; Thermo Fisher Scientific, Inc.) for $5 \mathrm{~h}$ at $37^{\circ} \mathrm{C}$ in humidified air containing $5 \% \mathrm{CO}_{2}$, in the presence of Cell Stimulation Cocktail (plus protein transport inhibitors;
eBioscience) consisting of phorbol 12-myristate 13-acetate $(81 \mathrm{nM})$, ionomycin $(1.34 \mu \mathrm{M})$, brefeldin A $(10.6 \mu \mathrm{M})$ and monensin $(2 \mu \mathrm{M})$. After $5 \mathrm{~h}$, cells were collected and incubated with PE-Cyanine5-conjugated CD3 (clone: UCHT1) monoclonal antibody $(0.6 \mu \mathrm{g} / \mathrm{ml}$; cat. no. 15-0038-42) for $30 \mathrm{~min}$ at $4^{\circ} \mathrm{C}$. The cells were then fixed and permeabilized with the Intracellular Fixation and Permeabilization Buffer Set following the manufacturer's protocol at room temperature and incubated with PE-conjugated IFN- $\gamma$ (clone: XMG1.2) monoclonal antibody (2.5 $\mu \mathrm{g} / \mathrm{ml}$; cat. no. 12-7311-82) and APC-conjugated IL-17A (clone: eBio64DEC17) monoclonal antibody $(0.6 \mu \mathrm{g} / \mathrm{ml}$; cat. no. 17-7179-42) for $30 \mathrm{~min}$ at room temperature (all from eBioscience). The same concentrations of species- and subtype-matched antibodies were used as negative controls: APC-conjugated Mouse IgG1 kappa Isotype Control (2.5 or $0.6 \mu \mathrm{g} / \mathrm{ml}$; cat. no. 17-4714-82), FITC-conjugated Mouse IgG1 Isotype Control (10 $\mu \mathrm{g} / \mathrm{ml}$; cat. no. MA1-10413), PE-Cyanine 5-conjugated Mouse IgG1 kappa Isotype Control (2.5 or $0.6 \mu \mathrm{g} / \mathrm{ml}$; cat. no. 15-4714-81), PE-conjugated Mouse IgG1 kappa Isotype Control $(2.5 \mu \mathrm{g} / \mathrm{ml}$; cat. no. 12-4714-82), APC-conjugated Rat IgG12a kappa Isotype Control $(5 \mu \mathrm{g} / \mathrm{ml}$; cat. no. 17-4321-81) and PE-conjugated Rat IgG1 kappa Isotype Control (2.5 $\mu \mathrm{g} / \mathrm{ml}$; cat. no. 12-4301-82) (all from eBioscience). Flow cytometry was performed on a Gallios flow cytometer (Beckman Coulter, Inc.), 5x10 4 events were acquired in each panel and data were analyzed using Kaluza Analysis software (version 2.1; Kaluza Software).

Statistical analysis. GraphPad Prism 6.0 statistical software (GraphPad Software, Inc.) was used for statistical analysis. Data were tested for normality using the Shapiro-Wilk test and are presented as the mean with standard deviation. Comparisons of the percentages of TCR $\gamma / \delta^{+} \mathrm{CD} 3^{+}$cells, $\mathrm{Foxp}^{+} \mathrm{CD}^{+}$cells, IFN- $\gamma^{+} \mathrm{CD}^{+}$cells, IL-17A ${ }^{+} \mathrm{CD}^{+}$cells, IFN $-\gamma^{+} \gamma \delta \mathrm{T}$ cells, and IL-17A ${ }^{+} \gamma \delta \mathrm{T}$ cells, and the expression pattern of CD27 and CD28 on $\gamma \delta$ T cells between groups were performed using Student's t-test. Correlations were analyzed using Pearson's correlation analysis. $\mathrm{P}<0.05$ was considered to indicate statistically significant differences.

\section{Results}

$\gamma \delta T$ cells are increased and Tregs are decreased in AR. The percentages of $\gamma \delta \mathrm{T}$ cells and Tregs in PBMCs of HC subjects and patients with AR were first detected. As expected, compared with HC subjects, the percentage of $\gamma \delta$ T cells was significantly increased, while the percentage of Tregs was significantly decreased in patients with AR (Fig. 1), suggesting that $\gamma \delta$ T cells may have an important role in the pathogenesis of AR, whereas the ability of Tregs to regulate immune homeostasis may be suppressed.

IFN- $\gamma^{+} \gamma \delta T$-cell subsets are decreased and IL-17A ${ }^{+} \gamma \delta T$-cell subsets are increased in AR. To further explore the role of $\gamma \delta \mathrm{T}$ cells in AR, the percentages of IFN- $\gamma^{+}$and IL-17A $\gamma \delta \mathrm{T}$ cells in PBMCs of $\mathrm{HC}$ and AR subjects were tested. Compared with that in $\mathrm{HC}$ subjects, the percentage of IFN- $\gamma^{+}$ $\mathrm{T}$ cells was significantly decreased, while the percentage of IL-17A ${ }^{+} \mathrm{T}$ cells was significantly increased in patients with AR (Fig. 2A-C). Unexpectedly, the expression of TCR $\gamma \delta$ 
Table I. Clinical characteristics of $\mathrm{HC}$ and AR subjects.

\begin{tabular}{lccc}
\hline Item & HC subjects $(\mathrm{n}=12)$ & AR subjects $(\mathrm{n}=14)$ & P-value \\
\hline Age (years) & $21(9-39)$ & $16(8-41)$ & 0.381 \\
Sex (male/female) & $6 / 6$ & $8 / 6$ & N/A \\
HDM-specific IgE $(\mathrm{IU} / \mathrm{ml})$ & $0.21(0.17)$ & $24.44(26.96)$ & $<0.001$
\end{tabular}

Values are expressed as $\mathrm{n}$, the median (range) or the mean \pm standard deviation. HC, healthy controls; AR, allergic rhinitis; HDM, house dust mite; N/A, not applicable.

A

$\mathrm{HC}$

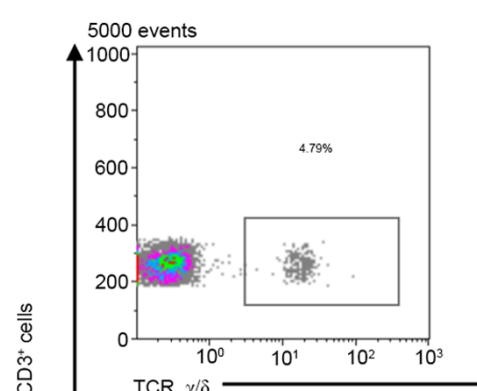

B

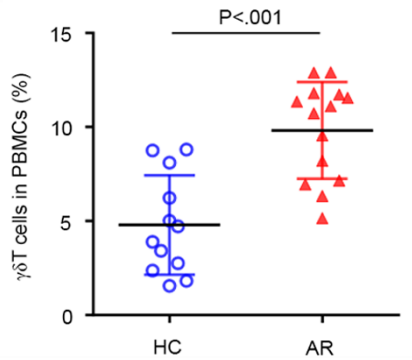

C

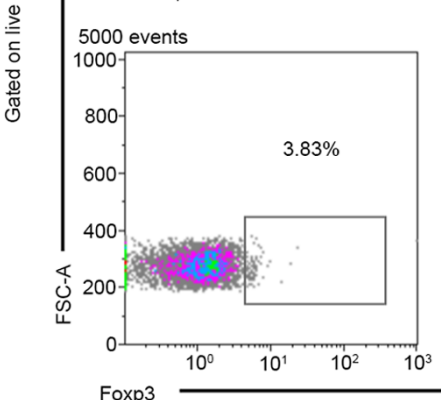

$A R$
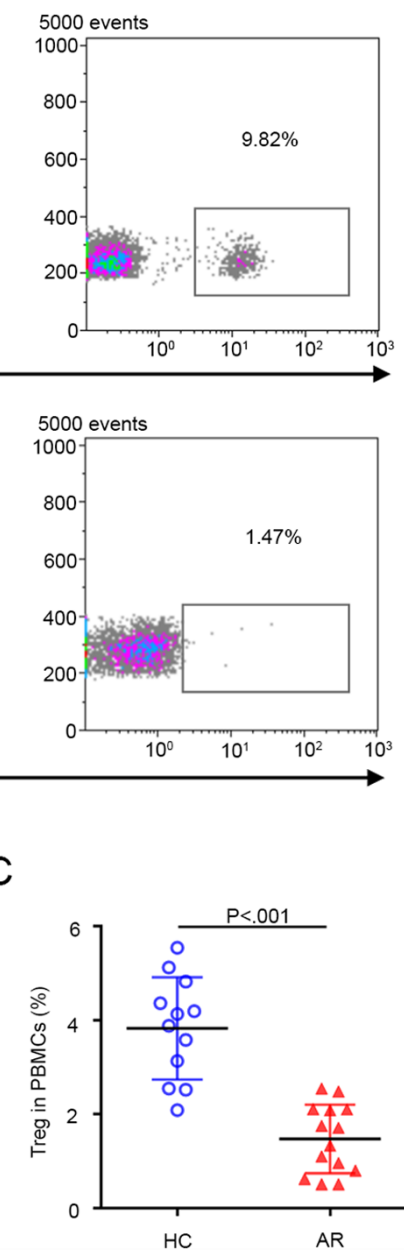

Figure 1. Increased $\gamma \delta$ T cells and decreased Tregs in AR. (A) Representative flow cytometry plots of the percentage of T-cell receptor $\gamma / \delta^{+}$and Foxp3 $3^{+}$ cells gated from live $\mathrm{CD}^{+} \mathrm{T}$ cells in PBMCs from $\mathrm{HC}(\mathrm{n}=12)$ and $\mathrm{AR}(\mathrm{n}=14)$ subjects. (B,C) Quantification of the percentage of $\gamma \delta$ T cells and Tregs in PBMCs. Values are expressed as the mean \pm standard deviation. AR, allergic rhinitis; HC, healthy controls; Fox, forkhead box; PBMCs, peripheral blood mononuclear cells; Treg, regulatory $\mathrm{T}$ cell.

was increased on both IFN- $\gamma^{+}$and IL-17A $\mathrm{A}^{+} \mathrm{T}$ cells in AR (Fig. 2A, D and E). Approximately half of the IFN- $\gamma^{+} \mathrm{T}$ cells were TCR $\gamma \delta$-positive, suggesting that $\gamma \delta \mathrm{T}$ cells may be the major source of IFN- $\gamma$ in AR. Furthermore, the expression of TCR $\gamma \delta$ on IL-17A ${ }^{+} \mathrm{T}$ cells in AR subjects was more than 2-fold higher compared with that in HC subjects, suggesting a non-negligible role of $\gamma \delta \mathrm{T}$ cells in promoting inflammation in
AR by significantly increasing the secretion of IL-17A. More importantly, the percentage of IFN- $\gamma^{+} \gamma \delta \mathrm{T}$ cells was significantly decreased and the percentage of IL-17A ${ }^{+} \gamma \delta \mathrm{T}$ cells was increased in AR (Fig. 2F-H), further supporting that the IFN- $\gamma^{+}$and IL-17A ${ }^{+} \gamma \delta$ T-cell subsets have important immune regulatory roles in AR.

Expression pattern of CD27 and CD28 on $\gamma \delta T$ cells in AR. The expression pattern of CD27 and CD28 on $\gamma \delta$ T cells was $\mathrm{CD} 27^{+} \mathrm{CD} 28^{+}>\mathrm{CD} 27^{-\mathrm{CD}} 28>\mathrm{CD} 27^{+} \mathrm{CD} 28>\mathrm{CD} 27^{-\mathrm{CD}} 28^{+}$in PBMCs from $\mathrm{HC}$ subjects. By contrast, this pattern was CD27 ${ }^{-} \mathrm{CD} 28>\mathrm{CD} 27^{+} \mathrm{CD} 28^{+}>\mathrm{CD} 27^{+} \mathrm{CD} 28>\mathrm{CD} 27^{-} \mathrm{CD} 28^{+}$in $\mathrm{AR}$ subjects (Fig. 3A). Overall, compared with HC subjects, the percentage of $\mathrm{CD} 27^{+} \gamma \delta \mathrm{T}$ cells was significantly decreased, while the percentage of $\mathrm{CD} 28^{+} \gamma \delta \mathrm{T}$ cells was significantly increased in patients with AR (Fig. 3A-C). Further analysis demonstrated that the percentage of $\mathrm{CD} 27^{+} \mathrm{CD} 28^{+} \gamma \delta$ T-cell subsets was significantly decreased in AR (Fig. 3D). The percentage of $\mathrm{CD} 27^{+} \mathrm{CD} 28^{-} \gamma \delta \mathrm{T}$-cell subsets in patients with AR was similar to that in $\mathrm{HC}$ subjects (Fig. 3E). The percentages of $\mathrm{CD} 27^{-} \mathrm{CD} 28^{+}$and $\mathrm{CD} 27^{-} \mathrm{CD} 28^{-} \gamma \delta \mathrm{T}$-cell subsets were both significantly increased in AR (Fig. 3F and G).

Correlation of CD27 and CD28 with $\gamma \delta$ T-cell subsets in AR. Next, the correlations between CD27 and CD28 expression on $\gamma \delta \mathrm{T}$ cells and IFN- $\gamma^{+}$or IL-17A $\mathrm{A}^{+} \gamma \delta \mathrm{T}$-cell subsets from patients with AR were analyzed. The results demonstrated that the percentage of the $\mathrm{CD} 27^{+} \mathrm{CD} 28^{+} \gamma \delta \mathrm{T}$-cell subset was positively correlated with that of the IFN- $\gamma^{+} \gamma \delta$ T-cell subset (Fig. 4A) and the percentage of the CD27 CD28 ${ }^{+} \gamma \delta$ T-cell subset was positively correlated with that of the IL-17A ${ }^{+} \gamma \delta$ T-cell subset (Fig. 4B). There was no correlation between the respective other combinations, for instance, between the $\mathrm{CD} 27^{+} \mathrm{CD} 28^{+} \gamma \delta$ T-cell subset with the IL-17A ${ }^{+} \gamma \delta$ T-cell subset and the CD27-CD28 ${ }^{+} \gamma \delta$ T-cell subset with the IFN- $\gamma^{+}$ $\gamma \delta$ T-cell subset (data not shown). These results suggested that CD28 is necessary for $\gamma \delta \mathrm{T}$ cells to produce cytokines, with the $\mathrm{CD} 27^{+}$subset producing IFN- $\gamma$ and the CD27- subset producing IL-17A.

Correlation of $\gamma \delta T$-cell subsets with Tregs in AR. Finally, the correlation between $\gamma \delta$ T-cell subsets and Tregs among the PBMCs of patients with AR was analyzed. The percentage of $\gamma \delta \mathrm{T}$ cells was negatively correlated with that of Tregs (Fig. 4C). In addition, the percentage of the CD27 CD28 $\gamma \delta$ T-cell subset was negatively correlated with that of Tregs (Fig. 4D), suggesting that the CD27-CD28 ${ }^{+} \gamma \delta$ T-cell subset 
A
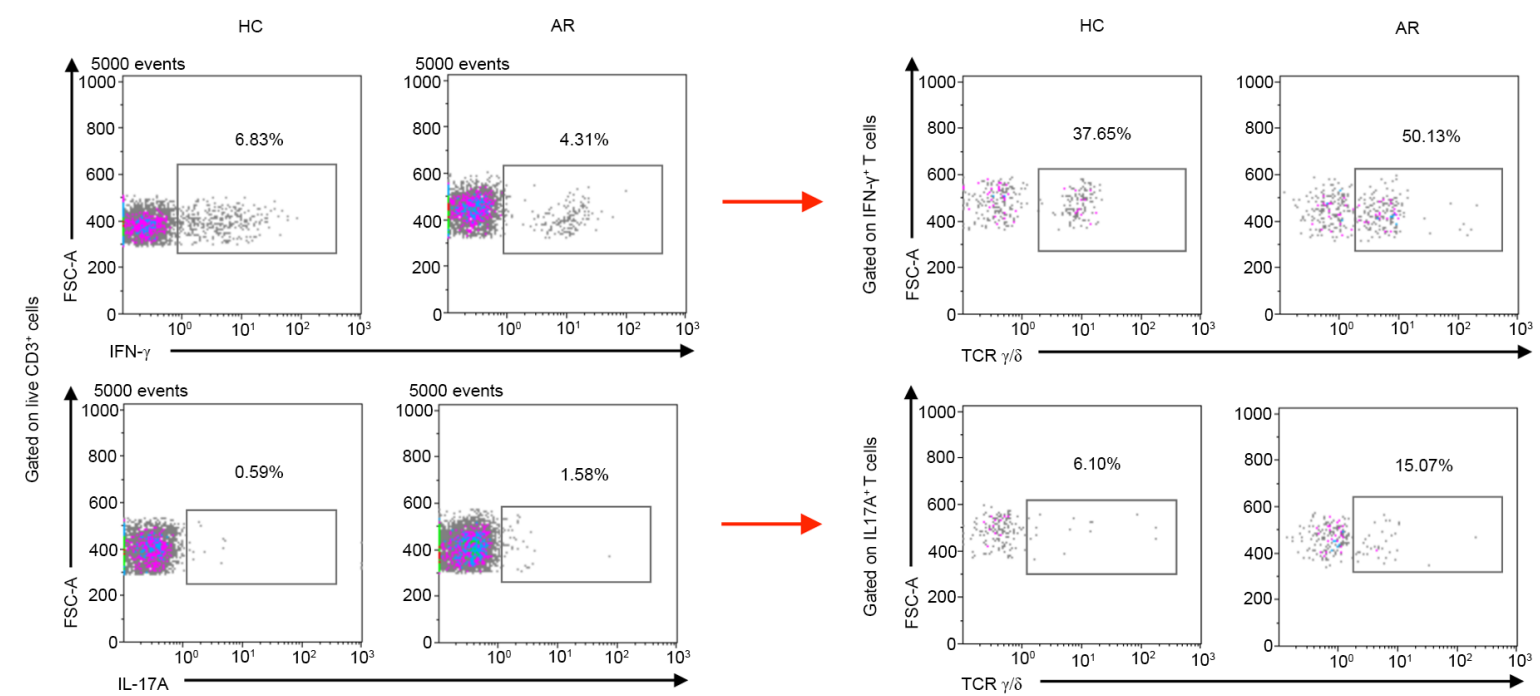

B

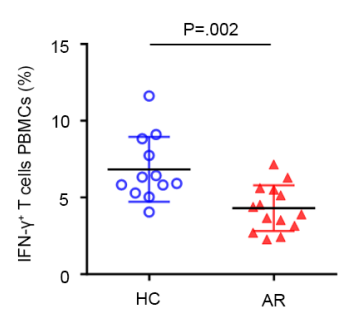

F

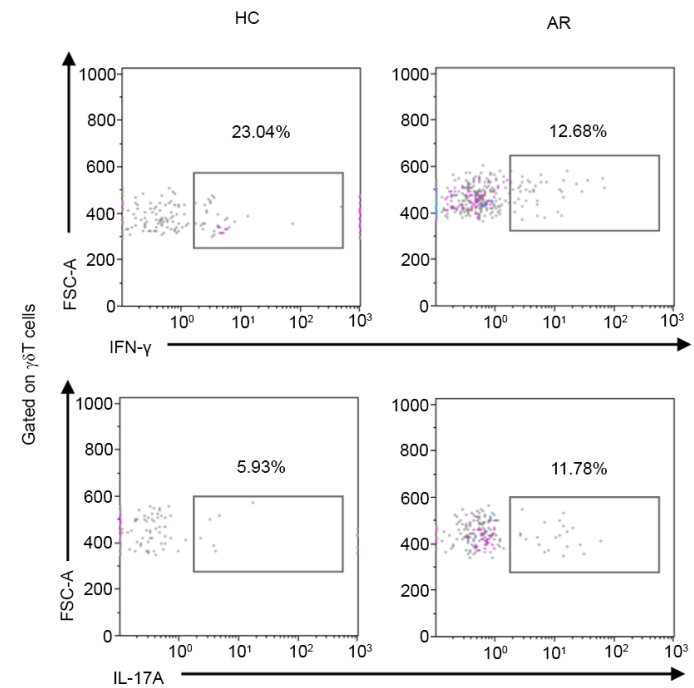

C
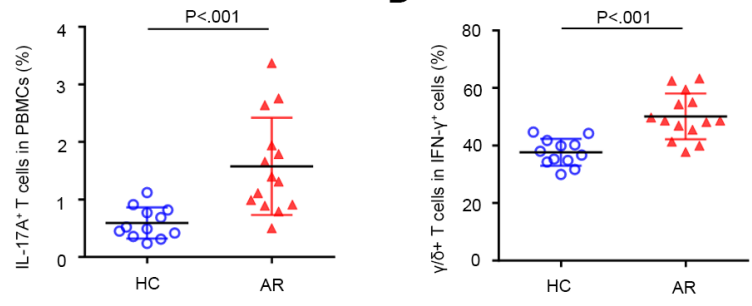

G

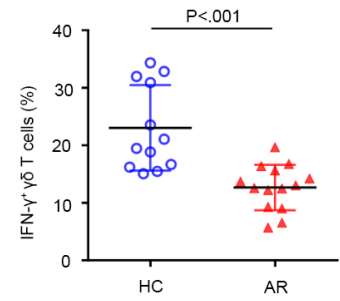

$E$

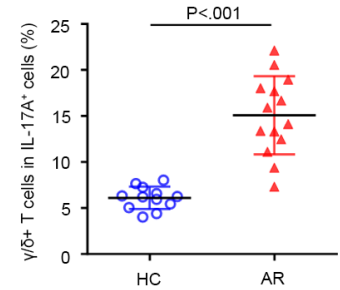

$\mathrm{H}$

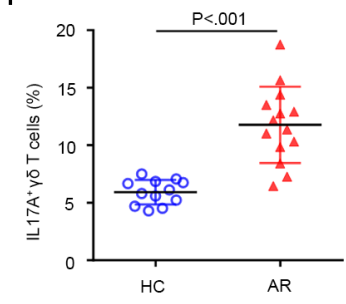

Figure 2. Decreased IFN- $\gamma^{+}$and increased IL-17A $\mathrm{A}^{+} \gamma \delta$ T-cell subsets in AR. (A) Representative flow cytometry plots of the percentage of IFN- $\gamma^{+}$and IL-17A cells gated on live $\mathrm{CD}^{+} \mathrm{T}$ cells and the percentage of TCR $\gamma / \delta^{+}$cells gated from IFN- $\gamma^{+}$and IL-17A $\mathrm{A}^{+} \mathrm{T}$ cells in PBMCs from HC $(\mathrm{n}=12)$ and AR ( $\left.\mathrm{n}=14\right)$ subjects (B-E) Quantification of the percentage of (B) IFN- $\gamma^{+}$and (C) IL-17A $\mathrm{A}^{+} \mathrm{T}$ cells in PBMCs and the percentage of (D) $\gamma \delta^{+} \mathrm{T}$ cells in IFN- $\gamma^{+}$and (E) IL-17A T cells. (F) Representative flow cytometry plots of IFN $\gamma^{+}$and IL-17A cells gated from $\gamma \delta$ T cells in PBMCs from HC $(n=12)$ and AR ( $\left.n=14\right)$ subjects. $(\mathrm{G}$ and $\mathrm{H})$ Quantification of the percentage of $(\mathrm{G}) \mathrm{IFN}-\gamma^{+}$and $(\mathrm{H}) \mathrm{IL}-17 \mathrm{~A}^{+} \gamma \delta$ T cells in PBMCs. Values are expressed as the mean \pm standard deviation. AR, allergic rhinitis; HC, healthy controls; PBMCs, peripheral blood mononuclear cells.

may be involved with the downregulation of the number and function of Tregs in AR.

\section{Discussion}

The results of the present study demonstrated that the elevated $\gamma \delta \mathrm{T}$ cells in the peripheral blood of patients with AR had an increased percentage of the $\mathrm{CD} 27^{-} \mathrm{CD} 28^{+} \gamma \delta$ T-cell subset, which was positively correlated with the percentage of IL-17A $\mathrm{A}^{+}$ $\gamma \delta \mathrm{T}$ cells and negatively correlated with Tregs. Furthermore, the percentage of the $\mathrm{CD} 27^{+} \mathrm{CD} 28^{+} \gamma \delta$ T-cell subset was significantly decreased and positively correlated with the percentage of IFN $-\gamma^{+} \gamma \delta$ T cells. Given that the IFN- $\gamma^{+}$and IL-17A ${ }^{+} \gamma \delta$ T-cell subsets have been indicated to exert antior pro-inflammatory effects on autoimmune diseases (16), the present results provide evidence supporting a potential 
A

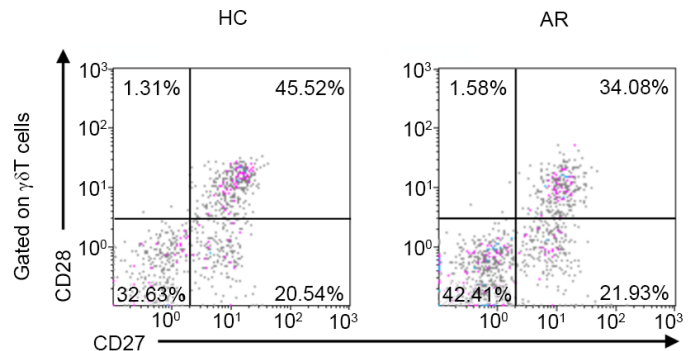

D

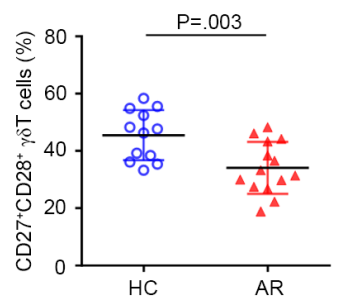

B

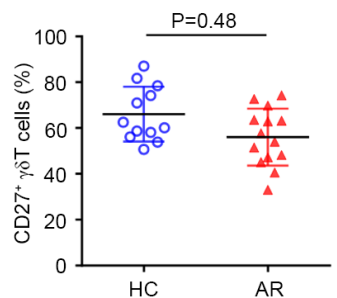

F

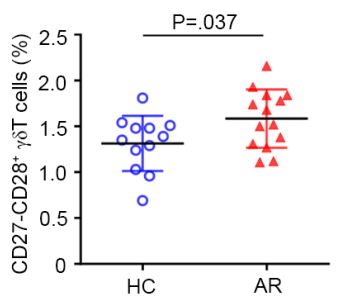

C

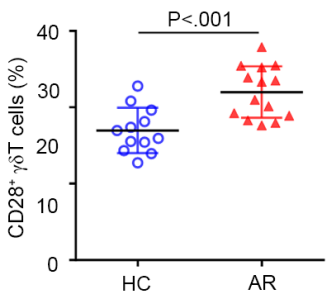

G

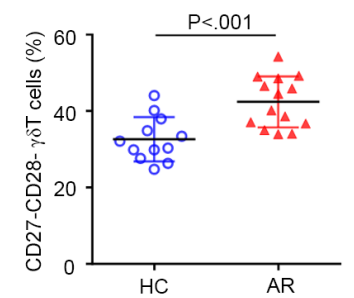

Figure 3. Expression pattern of CD27 and CD28 on $\gamma \delta$ T cells in AR. (A) Representative flow cytometry plots of the expression of CD27 and CD28 on $\gamma \delta$ T cells among PBMCs from HC $(n=12)$ and AR $(n=14)$ subjects. $(B-G)$ Quantification of the percentage of (B) CD27+, (C) CD28+, (D) CD27+CD28 ${ }^{+}$, (E) $\mathrm{CD}_{27} 7^{+} \mathrm{CD} 28^{-}$, (F) CD27-CD28 $8^{+}$and (G) CD27-CD28- $\gamma \delta^{+} \mathrm{T}$ cells in PBMCs. Values are expressed as the mean \pm standard deviation. AR, allergic rhinitis; $\mathrm{HC}$, healthy controls; PBMCs, peripheral blood mononuclear cells.
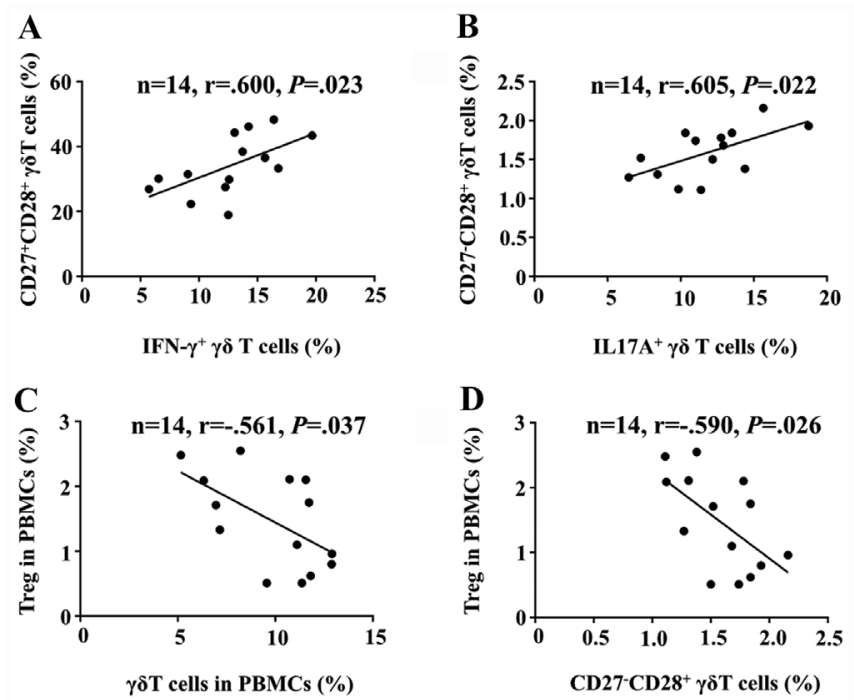

Figure 4. Correlation analysis of CD27 and CD28 $\gamma \delta$ T-cell subsets and Tregs in allergic rhinitis. (A) Correlation of the proportion of the $\mathrm{CD} 27^{+} \mathrm{CD} 28^{+}$ $\gamma \delta$ T-cell subset with that of the IFN- $\gamma^{+} \gamma \delta$ T-cell subset. (B) Correlation of the proportion of the $\mathrm{CD} 27 \mathrm{CD} 28^{+} \gamma \delta \mathrm{T}$-cell subset with that of the IL-17A $\gamma \delta$ T-cell subset. (C) Correlation of the proportion of $\gamma \delta$ T cells with that of Tregs. (D) Correlation of the proportion of the CD27-CD28+ $\gamma \delta$ T-cell subset with that of Tregs. PBMCs, peripheral blood mononuclear cells; Treg, regulatory $\mathrm{T}$ cell.

important role for CD27 and CD28 in the immune regulatory function of $\gamma \delta$ T cells in AR.

The major mechanism underlying AR has been indicated to be the dysfunction of the mucosal barrier, producing an overactive, unbalanced immune response against certain substances that are originally 'harmless' in vitro, such as allergens (1). Studies have proven that $\gamma \delta \mathrm{T}$ cells predominantly occur in the epithelium and mucosa and have an indispensable role in orchestrating the immune response of allergic diseases (17-20). In the present study, a significant elevation in the percentage of $\gamma \delta$ T cells in PBMCs from patients with AR was observed when compared with the control subjects, which is largely consistent with previous studies $(21,22)$, confirming the important role of $\gamma \delta \mathrm{T}$ cells in the pathogenesis of AR.

Previous studies have indicated that AR is characterized by a $\mathrm{T}$ helper type (Th) 2-skewed inflammation, with decreased levels of the Th1-associated cytokine IFN- $\gamma$ and increased levels of the Th17-associated cytokine IL-17A $(23,24)$. Consistently, the data of the present study also demonstrated a significant decrease in the percentage of IFN- $\gamma^{+}$and an increase in the percentage of $\mathrm{IL}-17 \mathrm{~A}^{+} \mathrm{T}$ cells in PBMCs of patients with AR compared with control subjects. The average percentage of IFN- $\gamma^{+}$T cells in $\mathrm{HC}$ subjects was $6.83 \%$, which was slightly lower than the range reported by other studies using similar experimental conditions $(25,26)$. This may be due to individual differences between the donors and future experiments with larger sample sizes may eliminate this difference. $\gamma \delta$ T cells are a major source of IFN- $\gamma$ and IL-17A in several autoimmune responses and lower airway allergic inflammations $(16,27)$; this may explain why the percentage of TCR $\gamma \delta^{+}$cells was significantly increased in the IFN- $\gamma$ - and IL-17A-producing T cells in patients with AR in the present study. Of note, the percentage of the IFN $-\gamma^{+} \gamma \delta$ T-cell subset was significantly decreased and that of the IL-17A ${ }^{+} \gamma \delta \mathrm{T}$-cell subset was significantly increased in AR, further supporting that the IL-17A ${ }^{+} \gamma \delta$ T-cell subset may have an important pro-inflammatory role in AR.

CD27, a member of the TNF receptor (TNFR) superfamily, and CD28, a member of the Ig superfamily, are typical T-cell costimulatory receptors that have specific roles in $\gamma \delta \mathrm{T}$ cells. They display different modes of intracellular signaling: CD27 requires the adaptor protein TNFR-associated factor, whereas CD28 associates directly with protein kinases to 
link to downstream signaling mediators (6). Studies in mice have demonstrated that CD27 and its ligand, CD70, are absolutely required for the survival, development, differentiation and function of $\gamma \delta$ T cells $(28,29)$. Another study in humans suggested that the majority of circulating $\mathrm{V} \gamma 9 \mathrm{~V} \delta 2^{+} \mathrm{T}$ cells express CD27, which acts as a coreceptor that promotes, in conjunction with TCR-mediated signals, the production of IFN- $\gamma$ (30). In $\alpha \beta$ T cells, the interaction of CD28 and its ligands, B7-1 (CD80) and B7-2 (CD86), provide a 'second signal' that is crucial for T-cell activation, proliferation and survival (31,32). Although the requirement of CD28/B7 signaling for the activation of $\gamma \delta$ T cells remains controversial (29), certain studies have revealed that CD28 is expressed on $\gamma \delta$ T cells in the lymph nodes and has the ability to promote the activation, proliferation and survival of $\gamma \delta \mathrm{T}$ cells, mainly via IL-2 secretion $(12,15)$. Data from a study on CD28-deficient mice revealed that the IFN- $\gamma^{+}$and IL- $17^{+} \gamma \delta$ T-cell populations failed to expand during infection (15), suggesting that CD28 is also required for the expansion of $\gamma \delta \mathrm{T}$ cells. In the present study, the decreased proportion of $\mathrm{CD} 27^{+} \mathrm{CD} 28^{+}$and increased proportion of $\mathrm{CD} 27^{-} \mathrm{CD} 28^{+}$and $\mathrm{CD} 27^{-\mathrm{CD}} 28^{-} \gamma \delta \mathrm{T}$ cells in the PBMCs of patients with AR, as well as the positive correlations of the CD $27^{+} \mathrm{CD} 28^{+} \gamma \delta \mathrm{T}$-cell subset with the IFN $-\gamma^{+} \gamma \delta$ T-cell subset, and of the CD27-CD28 ${ }^{+} \gamma \delta$ T-cell subset with the IL-17A ${ }^{+} \gamma \delta$ T-cell subset, suggest an aberrant activation and proliferation pattern of $\gamma \delta \mathrm{T}$ cells in AR and a different cytokine profile compared with that of healthy subjects.

Since first identified in 1995, the immunomodulatory effect of $\mathrm{CD} 4^{+} \mathrm{CD} 25^{+}$Tregs on the maintenance of immune homeostasis has been proven (33). It has been demonstrated that Tregs may inhibit excessive type I hypersensitivity by producing IL-10 and TGF- $\beta$, thereby having a pivotal role in the immune tolerance of allergens (34). It has been reported that the number and function of Tregs are significantly decreased in the peripheral blood during allergic airway inflammation (35). Furthermore, $\gamma \delta \mathrm{T}$ cells and Tregs may exert a synergistic regulatory effect in the pathogenesis of AR $(22,36)$. Since the specific transcription factor Foxp3 has a key role in the development and functional maintenance of Tregs (37), and is stably and constitutively expressed at a high level in $\mathrm{CD}^{+}{ }^{+} \mathrm{CD} 25^{+}$regulatory $\mathrm{T}$ cells, Foxp $3^{+} \mathrm{CD} 3{ }^{+}$cells in PBMCs were identified as Tregs in numerous studies $(38,39)$. Therefore, in the present study, only Foxp3 expression on $\mathrm{CD}^{+} \mathrm{T}$ cells was analyzed. It was observed that the percentage of Tregs was significantly decreased in patients with AR. More importantly, negative correlations were obtained between the percentage of Tregs with that of the CD27-CD28 ${ }^{+} \gamma \delta$ T-cell subset. These results suggest that the $\mathrm{CD} 27^{-} \mathrm{CD} 28^{+} \gamma \delta \mathrm{T}$-cell subset may have a role in the decrease of the number and function of Tregs in AR. However, as the percentage of the CD27-CD28+ $\gamma \delta$ T-cell subset was low, the function of $\mathrm{CD} 27^{-} \mathrm{CD} 28^{+} \gamma \delta \mathrm{T}$ cells must still be proven by further experimental studies.

In conclusion, the increased numbers of circulating $\gamma \delta$ $\mathrm{T}$ cells were characterized by an increased percentage of the $\mathrm{CD} 27^{-} \mathrm{CD} 28^{+} \gamma \delta \mathrm{T}$-cell subset, which was indicated to be positively correlated with the percentage of $\mathrm{IL}_{-17 \mathrm{~A}^{+} \gamma \delta}$ $\mathrm{T}$ cells and negatively correlated with Tregs in patients with AR. Furthermore, the decreased $\mathrm{CD} 27^{+} \mathrm{CD} 28^{+} \gamma \delta$ T-cell subset was positively correlated with the percentage of IFN- $\gamma^{+} \gamma \delta$
T cells. These data indicate the potentially important roles of CD27 and CD28 in the immune regulatory role of $\gamma \delta \mathrm{T}$ cells in AR. Given the limitations of the correlation analysis, it is necessary to fully verify the specific functions of CD27 and CD28 on $\gamma \delta$ T cells in AR via further experiments, such as cell experiments.

\section{Acknowledgements}

The authors gratefully acknowledge the guidance of the experiments by Dr Rui Zheng (Department of Otorhinolaryngology-Head and Neck Surgery, The Third Affiliated Hospital, Sun Yat-sen University, Guangzhou, China).

\section{Funding}

The present study was supported by the Science and Technology Program of Shenzhen Science and Technology Innovation Committee (grant no. JCYJ20180305163629056). The funding body has not influenced the study design, data collection, analysis or its interpretations.

\section{Availability of data and materials}

The datasets used and/or analyzed during the current study are available from the corresponding author on reasonable request.

\section{Authors' contributions}

QW contributed to the conceptualization and design of the study and drafted the manuscript. QS and QC performed the flow cytometry assays and helped draft the manuscript. HL and DL helped to analyze data. All authors read and approved the final manuscript.

\section{Ethics approval and consent to participate}

The present study was approved by the Ethics Committee of the Shiyan People's Hospital of Baoan District in Shenzhen City (Shenzhen, China). Written informed consent was provided by all subjects or their legal guardians prior to participation.

\section{Patient consent for publication}

Not applicable.

\section{Competing interests}

The authors declare that they have no competing interests.

\section{References}

1. Greiner AN, Hellings PW, Rotiroti G and Scadding GK: Allergic rhinitis. Lancet 378: 2112-2122, 2011.

2. Brozek JL, Bousquet J, Agache I, Agarwal A, Bachert C, Bosnic-Anticevich S, Brignardello-Petersen R, Canonica GW, Casale T, Chavannes NH, et al: Allergic rhinitis and its impact on asthma (ARIA) guidelines-2016 revision. J Allergy Clin Immunol 140: 950-958, 2017.

3. Pang DJ, Neves JF, Sumaria N and Pennington DJ: Understanding the complexity of $\gamma \delta$ T-cell subsets in mouse and human. Immunology 136: 283-290, 2012. 
4. Costa MF, Bornstein VU, Candea AL, Henriques-Pons A Henriques MG and Penido C: CCL25 induces $\alpha_{4} \beta_{7}$ integrindependent migration of $\mathrm{IL}-17^{+} \gamma \delta \mathrm{T}$ lymphocytes during an allergic reaction. Eur J Immunol 42: 1250-1260, 2012.

5. Dyring-Andersen B, Skov L, Løvendorf MB, Bzorek M Søndergaard K, Lauritsen JP, Dabelsteen S, Geisler C and Bonefeld CM: CD $4^{+} \mathrm{T}$ cells producing interleukin (IL)-17, IL-22 and interferon $-\gamma$ are major effector $\mathrm{T}$ cells in nickel allergy. Contact Dermatitis 68: 339-347, 2013.

6. Kohlgruber AC, Gal-Oz ST, LaMarche NM, Shimazaki M, Duquette D, Koay HF, Nguyen HN, Mina AI, Paras T, Tavakkoli A, et al: $\gamma \delta$ T cells producing interleukin-17A regulate adipose regulatory $\mathrm{T}$ cell homeostasis and thermogenesis. Nat Immunol 19: 464-474, 2018.

7. Petermann F, Rothhammer V, Claussen MC, Blanco LR, Heink S, Prinz I, Hemmer B, Kuchroo VK, Oukka M and Korn T: $\gamma \delta \mathrm{T}$ cells enhance autoimmunity by restraining regulatory $\mathrm{T}$ cell responses via an interleukin-23-dependent mechanism. Immunity 33: 351-363, 2010

8. Huang Y, Yang Z, McGowan J, Huang H, O'Brien RL and Born WK: Regulation of IgE responses by $\gamma \delta \mathrm{T}$ cells. Curr Allergy Asthma Rep 15: 13, 2015

9. Ullah MA, Revez JA, Loh Z, Simpson J, Zhang V, Bain L, Varelias A, Rose-John S, Blumenthal A, Smyth MJ, et al: Allergen-induced IL- 6 trans-signaling activates $\gamma \delta$ T cells to promote type 2 and type 17 airway inflammation. J Allergy Clin Immunol 136: 1065-1073, 2015.

10. Zheng R and Yang Q: The role of the $\gamma \delta \mathrm{T}$ cell in allergic diseases. J Immunol Res 2014: 963484, 2014.

11. Ribeiro ST, Ribot JC and Silva-Santos B: Five layers of receptor signaling in $\gamma \delta$ T-cell differentiation and activation. Front Immunol 6: 15, 2015.

12. Ribot JC and Silva-Santos B: Differentiation and activation of $\gamma \delta$ T lymphocytes: Focus on CD27 and CD28 costimulatory receptors. Adv Exp Med Biol 785: 95-105, 2013.

13. Ribot JC, deBarros A, Pang DJ, Neves JF, Peperzak V, Roberts SJ, Girardi M, Borst J, Hayday AC, Pennington DJ and Silva-Santos B: CD27 is a thymic determinant of the balance between interferon-gamma- and interleukin 17-producing gammadelta T cell subsets. Nat Immunol 10: 427-436, 2009.

14. Beyersdorf N, Kerkau T and Hünig T: CD28 co-stimulation in T-cell homeostasis: A recent perspective. Immunotargets Ther 4 111-122, 2015.

15. Ribot JC, Debarros A, Mancio-Silva L, Pamplona A and Silva-Santos B: B7-CD28 costimulatory signals control the survival and proliferation of murine and human $\gamma \delta$ T cells via IL-2 production. J Immunol 189: 1202-1208, 2012.

16. Peters C, Kabelitz D and Wesch D: Regulatory functions of $\gamma \delta$ T cells. Cell Mol Life Sci 75: 2125-2135, 2018.

17. Akitsu A and Iwakura Y: Interleukin-17-producing $\gamma \delta \mathrm{T}(\gamma \delta 17)$ cells in inflammatory diseases. Immunology 155: 418-426, 2018

18. Reyes NJ, Mayhew E, Chen PW and Niederkorn JY: $\gamma \delta$ T cells are required for maximal expression of allergic conjunctivitis. Invest Ophthalmol Vis Sci 52: 2211-2216, 2011

19. Takai T and Ikeda S: Barrier dysfunction caused by environmental proteases in the pathogenesis of allergic diseases. Allergol Int 60: 25-35, 2011.

20. Wu J, Xu L, Han X, Hu H, Qi F, Bai S, Chai R, Teng Y and Liu B Role of $\gamma \delta$ T cells in exacerbated airway inflammation during reinfection of neonatally primed mice in adulthood. $\mathrm{J}$ Med Virol 89: 2108-2115, 2017.

21. Xuekun H, Qintai Y, Yulian C and Gehua Z: Correlation of gammadelta-T-cells, Th17 cells and IL-17 in peripheral blood of patients with allergic rhinitis. Asian Pac J Allergy Immunol 32: 235-239, 2014

22. Yang Q, Li C, Wang W, Zheng R, Huang X, Deng H, Jin P, Tan K, Yan Y and Wang D: Infiltration pattern of gammadelta T cells and its association with local inflammatory response in the nasal mucosa of patients with allergic rhinitis. Int Forum Allergy Rhinol 9: 1318-1326, 2019.

23. Bajoriuniene I, Malakauskas K, Lavinskiene S, Jeroch J, Gasiuniene E, Vitkauskiene A and Sakalauskas R: Response of peripheral blood Th17 cells to inhaled Dermatophagoides pteronyssinus in patients with allergic rhinitis and asthma. Lung 190 487-495, 2012.
24. König K, Klemens C, Eder K, San Nicoló M, Becker S, Kramer MF and Gröger M: Cytokine profiles in nasal fluid of patients with seasonal or persistent allergic rhinitis. Allergy Asthma Clin Immunol 11: 26, 2015.

25. Baeten D, Van Damme N, Van den Bosch F, Kruithof E, De Vos M, Mielants H, Veys EM and De Keyser F: Impaired Th1 cytokine production in spondyloarthropathy is restored by anti-TNFalpha. Ann Rheum Dis 60: 750-755, 2001.

26. Migalovich Sheikhet H, Villacorta Hidalgo J, Fisch P, Balbir-Gurman A, Braun-Moscovici Y and Bank I: Dysregulated CD25 and cytokine expression by $\gamma \delta \mathrm{T}$ cells of systemic sclerosis patients stimulated with cardiolipin and zoledronate. Front Immunol 9: 753, 2018.

27. Zhao Y, Yang J and Gao YD: Altered expressions of helper T cell (Th) 1 , Th2 and Th17 cytokines in $\mathrm{CD} 8^{+}$and $\gamma \delta \mathrm{T}$ cells in patients with allergic asthma. J Asthma 48: 429-436, 2011.

28. Born WK and O'Brien RL: $\gamma \delta$ T cells develop, respond and survive-with a little help from CD27. Eur J Immunol 41: 26-28, 2011.

29. Ribot JC, debarros A and Silva-Santos B: Searching for 'signal 2': Costimulation requirements of $\gamma \delta$ T cells. Cell Mol Life Sci 68: 2345-2355, 2011.

30. DeBarros A, Chaves-Ferreira M, d'Orey F, Ribot JC and Silva-Santos B: CD70-CD27 interactions provide survival and proliferative signals that regulate $\mathrm{T}$ cell receptor-driven activation of human $\gamma \delta$ peripheral blood lymphocytes. Eur J Immunol 41: 195-201, 2011.

31. Lenschow DJ, Walunas TL and Bluestone JA: CD28/B7 system of T cell costimulation. Annu Rev Immunol 14: 233-258, 1996.

32. Smith-Garvin JE, Koretzky GA and Jordan MS: T cell activation. Annu Rev Immunol 27: 591-619, 2009.

33. Sakaguchi S, Sakaguchi N, Asano M, Itoh M and Toda M: Pillars article: Immunologic self-tolerance maintained by activated $\mathrm{T}$ cells expressing IL-2 receptor $\alpha$-chains (CD25). Breakdown of a single mechanism of self-tolerance causes various autoimmune diseases. J. Immunol. 1995. J Immunol 186: 3808-3821, 2011.

34. Palomares O,Martin-FontechaM,LauenerR, Traidl-Hoffmann C, Cavkaytar O, Akdis M and Akdis CA: Regulatory T cells and immune regulation of allergic diseases: Roles of IL-10 and TGF- $\beta$. Genes Immun 15: 511-520, 2014.

35. van de Veen W, Wirz OF, Globinska A and Akdis M: Novel mechanisms in immune tolerance to allergens during natural allergen exposure and allergen-specific immunotherapy. Curr Opin Immunol 48: 74-81, 2017.

36. Zheng R, Wu X, Huang X, Chen Y, Yang Q, Li Y and Zhang G: Gene expression pattern of Treg and TCR V $\gamma$ subfamily T cells before and after specific immunotherapy in allergic rhinitis. J Transl Med 12: 24, 2014.

37. Hori S, Nomura T and Sakaguchi S: Pillars article: Control of regulatory $\mathrm{T}$ cell development by the transcription factor Foxp3. Science 2003. 299: 1057-1061. J Immunol 198: 981-985, 2017.

38. Xue M, Liang H, Tang Q, Xue C, He X, Zhang L, Zhang Z, Liang Z, Bian K, Zhang L and Li Z: The protective and immunomodulatory effects of fucoidan against 7,12-Dimethyl benz[a] anthracene-induced experimental mammary carcinogenesis through the PD1/PDL1 signaling pathway in rats. Nutr Cancer 69: 1234-1244, 2017

39. Zhang X, Huang T, Wu Y, Peng W, Xie H, Pan M, Zhou H, Cai B and $\mathrm{Wu}$ Y: Inhibition of the PI3K-Akt-mTOR signaling pathway in T lymphocytes in patients with active tuberculosis. Int J Infect Dis 59: 110-117, 2017.

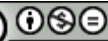

This work is licensed under a Creative Commons Attribution-NonCommercial-NoDerivatives 4.0 International (CC BY-NC-ND 4.0) License. 